\title{
1 Religion and Race: The Medieval Archive of Antisemitism
}

\section{The archive of antisemitism and the Swedish debate about Emancipation}

The history of minorities - religious, ethnic, sexual, or other - is both the history of groups of people with distinct features and specific self-identifications, and is also the history of the majority society creating a special status around these features. The question of who is regarded as a minority in a particular historical period, why this is so, and how societies treat minorities says a lot about the society itself and its identity.

The oppression and expulsion - but also interactions with, inclusion, and influences - of the Jewish minorities in Europe have been investigated as an integral part of European history for decades now. The history of antisemitism in particular has increasingly been regarded as the history of Christian societies' self-identification and self-assurance and not only as the history of a religious minority - even though antisemitism has obviously determined and still determines the living conditions of this group to a very great extent. But the history of the Jewish minority is not the same as the history of antisemitic knowledge and its development. Accessing the archive of knowledge via a specific corpus allows us to separate the history of a minority from the history of a figure of thought.

In the Nordic countries, the history of the Jewish minority in the medieval and early modern periods is exclusively a history of a present absence. Christian hostility arrived centuries before actual Jews settled in small numbers in the North. This hostility, conveyed in Christian texts, formed the nucleus of an archive of knowledge about "Jews" - the hermeneutic Jews found in theological polemics. Swedish people "knew" about Jews long before they met any real Jews. When the first generations immigrated, they intersected with a long history of hostility which had not had a concrete counterpart before. At the same time, international developments, particularly the Emancipation and assimilation processes in Europe, informed the influx and adaptation of new stereotypes and new forms of hostility, which arrived in Sweden at the same time as the first Jewish immigrants. It was towards the end of the eighteenth and during the nineteenth century that the transmitted "knowledge" about Jews encountered an actual Jewish minority, and the debates regarding the civil and political Emancipation of this minority were greatly informed by this older "knowledge." This phenomenon has been described using various terms; my own approach is

Ә OpenAccess. (C) $2022 \mathrm{He}$, published by De Gruyter. (cc) BY-NC-ND This work is licensed under the Creative Commons Attribution-NonCommercial-NoDerivatives 4.0 International License. 
perhaps closest to the Wissenssoziologie with which Jan Weyand has analysed the genesis of antisemitic thought in the German Empire. ${ }^{16}$ The approach is also inspired by David Nirenberg's brilliant attempt to reconstruct the "Western Tradition" 17 by detecting significant examples of attributing certain relatively stable figures of thought to "the Jew" in different historical periods. But while Nirenberg uses one single example per period (Martin Luther, Karl Marx), I attempt to reconstruct parts of the archive of anti-Jewish knowledge via the entire corpus of printed matter on the topic over the course of one century.

It is commonly accepted amongst scholars of antisemitism that the development of anti-Jewish hostility occurs relatively independent of the existence of an actual Jewish minority. Nevertheless, the history of modern antisemitism in Sweden has most often been discussed in the context of the presence, migration, and legal conditions of the Jewish minority - even though most research deals with the discursive developments of antisemitism. ${ }^{18}$ Consequently, focus has been on the process of Emancipation - and, given the fact that throughout the nineteenth century there were increasing possibilities for integration of the Jewish minority into the Swedish nation-state, culminating in Emancipation in 1870, this has most often been told as a success story. However, the predominance of this "all's well that ends well" conclusion has led to a peculiar ignorance regarding the simultaneous existence of antisemitism independent of the increased integration of actual Jews. One example is Rita Bredefeldt, who paraphrases the pre-history of Emancipation as a series of anti-Jewish protests but still concludes on a positive note:

16 Jan Weyand, Historische Wissenssoziologie des modernen Antisemitismus: Genese und Typologie einer Wissensformation am Beispiel des deutschsprachigen Diskurses (Göttingen: Wallstein Verlag, 2016).

17 David Nirenberg, Anti-Judaism: The Western Tradition (New York: Norton, 2013).

18 See, for example, Kristian Gerner, "Degrees of Antisemitism: The Swedish Example," in Jews and Christians: Who Is Your Neighbour After the Holocaust? A Polish-Swedish Colloquium on Jewish-Christian Dialogue, ed. Michał Bron, Acta Sueco-Polonica Bokserie 2 (Uppsala: Seminariet i Polens Kultur och Historia vid Uppsala Universitet, 1997); Carl H. Carlsson, Medborgarskap och diskriminering: Östjudar och andra invandrare i Sverige 1860-1920, Acta Universitatis Upsaliensis 215 (Uppsala: Univ, 2004); Per Hammarström, “Judar öfversvämmar landet': Den judiska gårdfarihandeln i Kungl. Maj:ts befallningshavandes femårsberättelser 1865-1905,” in Den nya staten: Ideologi och samhällsförändring kring sekelskiftet 1900, ed. Erik Nydahl and Jonas Harvard (Lund: Nordic Academic Press, 2016). 
Trots judefientliga protester hos breda folklagar och press 1815, 1838, 1848 och under 1850och 1860-talen, blev 1800-talet emancipationes århundrade för den första gruppen av västeuropeiska judar som bosatt sig i Sverige.

(Despite anti-Jewish protests in large parts of the population and the press in 1815, 1838, 1848 , and during the 1850s and 1860s, the nineteenth century became the century of Emancipation for the first group of West European Jews who settled in Sweden. ${ }^{19}$

Many other scholars follow the same narrative, which was established by Hugo Valentin, the first and most influential scholar of Swedish Jewish history. Valentin identifies antisemitism in parliamentary debates, newspapers, and various other discourses, but he still describes the history of the Jewish minority as a story of success, because Emancipation was finally realized and the Jewish presence in the country secured. This narrative has been crucial to the self-understanding and self-assertion of the Jewish minority in Sweden, but it obstructs an analysis of the development of antisemitism, particularly before 1870. In most of the years before 1870 various measures to modify the judereglemente were discussed (and often rejected) while Jews were immigrating, sometimes getting baptized and sometimes not, and Jewish communities were being established in more and more Swedish towns. At the same time, there was an undercurrent to these developments which did not follow its more or less linear trajectory of liberalization: the production, distribution, and reception of texts with "Jewish" themes, in which the archive of antisemitism was preserved, developed, and updated. These texts form a corpus which reflects contemporary debates and developments but which also contains a considerable quantity of conservative and much older elements: medieval model texts, narrative traditions from the early modern period, and other topics which had nothing to do with the contemporary modernization of Swedish society. In light of this corpus, held together solely by the presence of "Jewish" themes, the nineteenth century appears not so much as a period of change but rather of continuity: continuity of religious narratives and their popularity, continuity of certain legends, motifs, and figures, and continuity of literary traditions. While the analysis of newspaper debates or parliamentary debates provides an opportunity to detect and describe innovations, novelty, and change, the printed books shine light on the conservative and long-lasting elements which make up collective knowledge and memory even at the same time as innovation occurs.

19 Rita Bredefeldt, “De judiska minoriteterna i Sverige och Finland - olika men ändå lika,” in Från sidensjalar till flyktingmottagning: Judarna i Sverige - en minoritets historia, ed. Lars M. Andersson, Opuscula historica Upsaliensia 50 (Uppsala: Swedish Science Press, 2013), 58. 
Antisemitic ideas and stereotypes are latent components of collective knowledge, existing over extended periods of time but leading to specific outbreaks in specific historical circumstances. Sweden has had comparatively few outbreaks of anti-Jewish violence, yet there have been underlying constant streams and also sudden surges of anti-Jewish textual production. During the nineteenth century, anti-Jewish textual production consisted of texts handed down since the Middle Ages as well as new productions, both translations and domestic works. In some fields, discussions about changes to the legal and political status of the Jewish minority provoked this text production; in others, there was no chronological correlation between government debates, policy changes, and text production.

The "archive" is a more or less systematic collection of different kinds of sources, collected in different historical periods and stored in a common room of collective ideas and ideologemes. The concept of the "archive" provides a metaphor for collective memory, knowledge, and the subconscious: a room full of files ordered according to their provenance rather than their subject matter or content, covering long historical periods, and structuring historical knowledge according to the strict and immutable principles and rules developed for all archives. The image of the archival storage space also allows for the fact that there are parts missing from collective knowledge, absences caused by earlier losses of archival holdings through external factors, such as fires or wars, or by the structure of the holdings themselves, which necessarily omit certain large areas of source production and yet are still considered to be the most comprehensive foundations of historical knowledge we have access to. The archive is in this sense closer to the actual archival institution and building than concepts which use it as a metaphor only vaguely connected to the institutionalized processes of storing, remembering, and forgetting.

Michel Foucault, Jacques Derrida, and, inspired by these, Aleida Assmann have shifted the notion of the archive from a place where knowledge is stored to one where it is produced. As long as the content of the archive is not canonized as an integral part of cultural knowledge and memory, and as such constantly remembered and staged, it becomes a passive knowledge, halfway between being remembered and forgotten. Understanding the principles and structure of the archive means understanding the structure behind contemporary evidence of outbreaks of antisemitism; this radically challenges the perception that antisemitism is nothing but a "foreign import" to Scandinavia. Instead, the concept of the archive makes it possible to analyse various national and international sources of knowledge and information about "Jews," which do not necessarily rely on the existence or presence of actual Jews. It also allows for 
the integration of religious or mythical as well as secular fragments of knowledge, all of which inform modern antisemitism.

The concept of the archive has not been widely used to examine the dissemination and development of anti-Jewish notions in the North, but Ragnhild Henden has used it to examine the development of ideas about Jews in Norwegian crime novels. She points out that the concept allows the focus to shift from an actor-centred perspective of power to the abstract and impersonal power of the archive itself. Relevant questions are how and why certain stories are being told and others forgotten and how this influences the development of anti-Jewish perceptions and imaginaries. ${ }^{20}$

Much like most of the concepts regarding discourse used today (from Foucault to Habermas), the concept of the archive is difficult to grasp and to analyse in historical scholarship. Nevertheless, it has the potential to illuminate a significant part of collective knowledge. Formed out of texts, events, debates, and other textual and non-textual, performative and static, individual and collective memories, the archive cannot be fully reconstructed. Within the present study, the focus on printed texts constitutes a significant limitation for the reconstruction of the archive, since other important forms of discourse are missing: most newspaper debates and speeches at the Riksdag (a small number of these were printed separately and thus fall within the scope of this study) and all non-textual and performative elements, such as sermons, demonstrations, and public and academic lectures. On the other hand, printed books include at least excerpts from many different discourses: scholarly production from the scientific discourse, selected speeches from the diets and offentliga tryck ${ }^{21}$ from the political discourse, selected sermons from the ecclesiastical discourse. Even though printed books are usually intended to be readable and usable for a longer period, and even though book production can be a lengthy and complicated process, some of the material in the corpus consists of immediate responses to ongoing or very recent events. In some cases, the reference to the event might have been inserted at the last minute, but often, print production was characterized by quick, small, and cheap products containing material that might even have been suitable for leaflets, broadsheets, or as newspaper inserts. Further-

20 Ragnhild Henden, “Tidlig norsk kriminallitteratur og det antisemittiske arkiv,” in Forestillinger om jøder: Aspekter ved konstruksjonen av en minoritet 1814-1940, ed. Vibeke Moe and Øivind Kopperud (Oslo: Unipub, 2011).

21 Offentliga tryck (public prints) is a collective term for various types of texts issued by public administration on the national or communal level. Examples include acts and protocols from the Riksdag, statistics, protocols from other government bodies, collections of constitutional documents, and laws. 
more, printed copies of government regulations, speeches made in parliament, and the concluding files from trials all deal with questions related to Jews and add to the impression that the Jewish presence in the country was a huge problem or at least issue. In some years, it is clear that printed texts of motions to the Riksdag, government publications of new rules, and public debates coincided with and provoked an increased production of printed books and booklets about Jews. This is particularly true for the years 1815 and 1838, in which the government attempted to grant Jews in Sweden more rights but abandoned these plans due to public resistance.

When assessing a specific corpus on one topic and in one language, the question of literacy also becomes relevant - we know that anti-Jewish knowledge was largely transmitted via oral and material media in the Middle Ages (sermons, church paintings, etc.). In modern Sweden, parish priests' visitation protocols suggest that even before the creation of a general school system in 1842, literacy in all social groups was very high, and nine out of ten Swedes were able to read in $1800 .^{22}$ While we cannot know which people read any specific book, it is nonetheless possible to say that during the nineteenth century the majority of the population had access to printed texts and was able to read Swedish. Consequently, while the reconstruction of the archive from printed books is far from complete, we know that it would have been accessible to many different people and potential audiences.

While it is impossible to determine the specific archive of texts and knowledge one specific author will have had access to at the moment of writing, analysis of a variety of texts over an extended period of time allows for the detection of certain themes and motifs which emerged out of the various discourses. To continue with the image of the archive: certain folders in which unorganized papers and files are bundled together, all of them filed under the larger heading "Jews." The aim of the present study is a partial reconstruction of these archival folders: which texts were produced during the nineteenth century in Swedish dealing with Jewish topics in a broad sense? What kind of "knowledge" about Jews did they carry with them, and where did they draw this knowledge from? The historical circumstances of the simultaneously developing legal conditions for Jewish settlement provide a background to this, but, as will be shown, in many cases they were completely unrelated to the text and knowledge production.

22 See Daniel Lindmark, Reading, Writing and Schooling: Swedish Practices of Education and Literacy, 1650-1880 (Umeå: Institutionen för litteraturvetenskap och nordiska språk, Umeå universitet, 2004). 


\section{Medieval antisemitism and supersessionism}

Medieval and pre-modern forms of hostility towards Jews are rooted in religious difference, but this is combined with other forms of difference, which are in part a consequence of the religious difference, in part stereotypes and ascriptions. Religious difference had many consequences in pre-modern Christian societies: a different legal status with different legal rules and rituals (this was true even in the ancient world and in Muslim societies), in some cases separate residential areas, organization of craftsmen outside of guilds, and different jurisdictions. These consequences did not all necessarily indicate hostility, they were just a result of the fact that most functions of community-building were connected to the community of Christians, which was not adapted to the integration of religious minorities, heretics, excommunicants, and the like, and that legal systems needed a specific place for these. The comprehensive and multi-layered exclusion of Jews from Christian communities did, however, establish a status of difference which went beyond the religious. Christian theology developed a radically different idea of "the Jew," with a different religion, character, temporality, and physiognomy. All of these ascriptions were developed in relation to the religious difference, which in this context was not neutral: religious difference implied Christian supersessionism, accusations of deicide, the blood curse, and many other consequences. Many of these complex connections between religious difference, legal difference, and stereotypical ascriptions were no longer intelligible in modern societies - but the general feeling, or "knowledge," that Jews were different on many levels remained intelligible. This is why it is important to uncover the medieval roots of modern anti-Jewish knowledge.

Scholars of medieval history have argued that certain definitions of race and racism can be applied to medieval forms of anti-Jewish hostility. James Thomas, for example, has been working with a definition of racism as something that "signifies and symbolizes social conflicts and interests by referring to different types of human bodies." 23 This definition obviously fits with the medieval processes whereby Jews were first assigned a collectively bad character - a consequence of the deicide accusation, with this character subsequently signified and portrayed by specific physical traits. ${ }^{24}$

23 The definition stems from Michael Omi and Howard Winant. See James M. Thomas, "The Racial Formation of Medieval Jews: A Challenge to the Field," Ethnic and Racial Studies 33, no. 10 (2010): 1739.

24 On the question of medieval racist antisemitism in general, see Jonathan Adams and Cordelia Heß, eds., The Medieval Roots of Antisemitism: Continuities and Discontinuities from the Mid- 
Modern definitions of racism focus on the social construction of race, in order to differentiate between physical differences and the various forms of oppression, marginalization, and social stratification they have led and continue to lead to. Applying these definitions to medieval societies is difficult because these societies were characterized by a much more comprehensive stratification: people were differentiated by gender, age, family relations, ethnicity, religion, economic standing, and other attributes, and most of these factors translated into a specific legal status. Marginalization, in the sense of being differentiated from the majority society, is a difficult term to use in this context because it applied to most people in some sense. Thus, the religious difference which led to the legal marginalization of Jews in Christian societies was absolute and yet was also connected to a complex system of legal marginalization which affected various groups within Christian society. Jews were not the only ones to have a special legal status as a result of their difference, and they were not the only ones marginalized by this status. But unlike many other marginalized groups, this status was accompanied by comprehensive anti-Jewish polemics which surrounded, justified, and manifested it. In these polemics, Jewish religious difference was constructed with markers resembling modern racist markers; i.e., physical difference, collective character traits, etc.

These markers were attributed to "Jews" as a result of the theological discussions, legends, and sermons interpreting and embellishing biblical and apocryphal figures: the Jews scorning and torturing Jesus, Judas, Pontius Pilate (who was often perceived as Jewish), the crowd in Jerusalem calling for Barabbas to be freed and Jesus to be crucified. The collective identification of these figures with "the Jews" created the possibility for an equally collective ascription of racist markers and, even more pertinently, it connected these apocryphal figures to contemporary Jews and ascribed to them a physical, essential, and biological coherence and continuity - a specific Jewish temporality shaped in medieval Passion piety, which remained functional and intelligible in the modern period. The Christian focus on different Jewish characters and their respective actions during the Passion of Christ developed in the Late Middle Ages, stemming from a spiritual focus on the Passion and humanity of Christ and a simultaneous ascription of guilt for his suffering to Jews as a collectivity - past, present, and future.

This is important to keep in mind when investigating the racist elements in early nineteenth-century antisemitism: the polemics had a long history behind them and remained well used and practised even though the legal status con-

dle Ages to the Present Day (New York: Routledge, 2018); Geraldine Heng, The Invention of Race in the European Middle Ages (Cambridge: Cambridge University Press, 2018). 
nected to religious difference was about to change or had already changed. Herein lies a fundamental difference between the German lands, France, Poland, and other European countries, on the one hand, and the Nordic countries, on the other - in most areas on the continent, Jewish communities with a specific legal status had been known as neighbours for centuries and, in many places, their legal status had already been adjusted to that of the majority society. In Sweden, the status of the Jewish community as a kahal (separate community with a special legal status) was created with the judereglemente, and it did not change until 1838 - in many regards, not until 1870.

Another aspect of religiously grounded anti-Jewish hostility which had persisted since the Middle Ages was supersessionism, and this aspect is very visible in the Swedish material. A broad definition of supersessionism is required to encompass all the various ways of labelling Judaism as obsolete, outdated, and simply wrong which were used from antiquity until the nineteenth century (and in many cases, were not questioned until after the Holocaust). Theologians have developed a typology of punitive, economic, and structural supersessionism. ${ }^{25}$ Of these, punitive supersessionism is the most prominent in the modern Swedish material. Supersessionism originally developed from the need Christians felt to delimit their own faith from Judaism and to solve certain incongruities deriving from problems in the conversion of Jews and gentiles and the emerging differences in ritual. While Christians still believed in the promises made by God in the Hebrew Bible, they had to explain why these promises no longer applied to the Jews but to the Christians themselves. There were several ways to explain this, all of them already developed by the Church Fathers and most of them described under the umbrella term "supersessionism," which covers various ways in which the early Church in particular conceptualized its relation to Israel and to the covenant of the Hebrew Bible. ${ }^{26}$

Origen stated that the Jews were being punished for their refusal to accept Jesus as the messiah, and ultimately for killing him. Augustine instead put forth an early version of fulfilment theology, meaning that the Christian Church fulfilled all the promises God made to the people of Israel in the Hebrew Bible. The Jews' role as "witnesses" plays an important part in his theology. Both the original intent and medieval practice of this doctrine are fiercely debated; recently, Gregory W. Lee has suggested that Augustine conceptualized the Jews as occupying a third position between the City of God and the City of Evil: an enslaved

25 See Michael J. Vlach, Has the Church Replaced Israel? A Theological Evaluation (Nashville: B\&H Academic, 2010).

26 Michael G. Azar, “Origen, Scripture, and the Imprecision of 'Supersessionism', Journal of Theological Interpretation 10, no. 2 (2016). 
people who have failed to acknowledge the truth but are nevertheless preserved by God in order to bear witness to his law. ${ }^{27}$ Another idea that was prevalent in medieval theology was that Jewish feasts commemorating the most important events in the relationship between God and Israel had lost their significance after the Passion of Christ. ${ }^{28}$ It must, however, be noted that the original theological debates of the Church Fathers, especially Augustine's comparatively tolerant approach towards Jews and Judaism, were subject to many modifications and reformulations during the Middle Ages, not least to justify the Crusades and other waves of pogroms.

In addition to the theological discourse of the Church Fathers, the literature of late antiquity also popularized the idea of punitive supersessionism. For example, the actual Jewish exile from Jerusalem following the destruction of the Temple in 77 CE was cited in this regard in Prudentius's Apotheosis, written ca. 400 CE:

From place to place the homeless Jew wanders in ever-shifting exile, since the time when he was torn from the abode of his fathers and has been suffering the penalty for murder, and having stained his hands with the blood of Christ whom he denied, paying the price of $\sin ^{29}$

It might be argued that supersessionism, in its different variations, was actually at the root of Christian hostility towards Jews. In particular, the connection between punitive supersessionism and the deicide accusation constituted a strong justification for expulsion and oppression. Jews were accused of being blind and stubborn - a tried and tested argument going back to the Church Fathers and John Chrysostom's Adversus Iudaeos sermons. Jewish rootlessness was simultaneously seen as a character trait and as a punishment for the deicide - another argument from the Church Fathers, who pointed to the biblical destruction and rebuilding of the First Temple as an example of the eternal but futile desire to return to the Holy Land. Ancient, medieval, and early modern theologians debated whether Christians should let Jewish people live as visible reminders of the

27 Gregory W. Lee, "Israel between the Two Cities: Augustine's Theology of the Jews and Judaism," Journal of Early Christian Studies 24, no. 4 (2016). More generally, the latest monographic study on Augustine's doctrine of witness is Paula Fredriksen, Augustine and the Jews: A Christian Defense of Jews and Judaism (New Haven: Yale University Press, 2010).

28 Matthew A. Tapie, Aquinas on Israel and the Church: The Question of Supersessionism in the Theology of Thomas Aquinas (Cambridge, England: James Clarke \& Co, 2015).

29 Aurelius Prudentius Clemens, Prudentius: In Two Volumes. Translated by Henry John Thomson, vol. 1, reprinted, the Loeb classical library 387 (Cambridge, Mass.: Harvard University Press, 2000), 160. 
obsolescence of their faith and covenant with God, or whether they should just get rid of them. As such, supersessionism was not just an incredibly arrogant view of another faith, it was plainly dangerous.

Conversion from Judaism to Christianity has been a contested topic in the history of Jewish-Christian relations. Christian eschatology expected all Jews to convert at the end of times (all pagans as well). The possibility of conversion might be seen as an argument against a racist or essentialist determination of Christian concepts of "Jews": if baptism could wash off the Jewishness, it could not be grounded in the body. But as early as the 1350s, Christians raised doubts as to this possibility: during the Plague in Europe, it was in many places the baptized Jews - or, as sources referred to them, "secret Jews" - who were accused of poisoning wells and engaging in conspiracies to destroy Christianity. ${ }^{30}$ In the first decades of the sixteenth century, the idea that converts were not to be trusted in the same way as "true" Christians culminated in the practices of the Spanish Inquisition and the sophisticated methods it used to interrogate Jewish and Muslim conversos.

In terms of the relation between modern antisemitism and its medieval roots, or at least the perception thereof, one last aspect deserves mention. A common view in modern studies of antisemitism is that the connection between Jews and money is based on medieval Jewish economic activities and exclusion from the Christian guilds and professions. Recent studies by medieval scholars such as Michael Toch and Giacomo Todeschini have disputed this view, showing it to be overly simplistic: while it is true that Jews were active in moneylending, these activities were not nearly as exclusive as suggested. Jews owned land, were active in all kinds of handicrafts and trades, as merchants, artists, and in all other fields of everyday life. Many of them were also just poor and are thus poorly visible in the sources. ${ }^{31}$ The Christian campaign against usury was for a long time an internal Christian issue, and its conflation with anti-Jewish resentment is a relatively late projection of this issue onto the religious Other. ${ }^{32}$ De-

30 See Cordelia Heß, "Jews and the Black Death in Fourteenth-Century Prussia: A Search for Traces," in Fear and Loathing in the North: Jews and Muslims in Medieval Scandinavia and the Baltic Region, ed. Jonathan Adams and Cordelia Heß (Berlin: De Gruyter, 2015).

31 Michael Toch, The Economic History of European Jews: Late Antiquity and Early Middle Ages, Études sur le Judaïsme Médiéval (Leiden: Brill, 2012).

32 Giacomo Todeschini, "Usury in Christian Middle Ages: A Reconsideration of the Historiographical Tradition (1949-2010),” in Religione e Istituzioni Religiose nell'economia Europea: 1000-1800; Religion and Religious Institutions in the European Economy; Atti della "Quarantatreesima Settimana di Studi”, 8-12 Maggio 2011, ed. Francesco Ammannati, Fondazione Istituto Internazionale di Storia Economica "F. Datini", Prato Serie 2, Atti delle "settimane di studi" e altri convegni 43 (Firenze: Firenze University Press, 2012). 
spite these arguments, the common perception is that the connection of Jews and money stems from their exclusion from Christian guilds in the Middle Ages and their consequent dominance of the money trade. Julie Mell has shown that even the scholarly focus on medieval Jews and moneylending is a construction of nineteenth-century historiography. ${ }^{33}$ In nineteenth-century Sweden, however, that connection was enjoying its heyday and was highly visible, particularly in caricatures and satirical texts about Jews. But unlike the other forms of medieval hostility towards Jews, such as punitive supersessionism and the construction of "Jews" as an eternal collectivity with negative character and physical traits, the connection of Jews and money was not of medieval origin.

\section{Religious homogeneity and Swedish Frühantisemitismus}

While the process of Emancipation of the Jewish minorities on a legal and cultural level has been the focal point of historical research on the continent for decades now, the same process is strangely under-researched in Sweden. Most research about relations between the Jewish minority and the Christian majority focuses on later periods, from 1870 on, ${ }^{34}$ with particular attention paid to the 1930s and 40s. ${ }^{35}$ The granting of full civil rights to Jews in Sweden, as decided in the Riksdag of 1870, is usually considered the beginning of Jewish history in Sweden proper - however, it can also be seen as but one step in a long history of relations. ${ }^{36}$ At the same time, the increasing immigration of Jews from Poland

33 Julie L. Mell, The Myth of the Medieval Jewish Moneylender, 2 vols, Palgrave Studies in Cultural and Intellectual History (Cham: Palgrave Macmillan, 2018).

34 Lena Berggren, Nationell upplysning: Drag i den svenska antisemitismens idéhistoria (Stockholm: Carlsson, 1999); Lena Berggren, Blodets renhet: En historisk studie av svensk antisemitism (Malmö: Arx Förl, 2014); Christoph Leiska, Räume der Begegnung - Räume der Differenz. Jüdische Integration und Antisemitismus in Göteburg und Kopenhagen 1850-1914 (Berlin: Metropol Verlag, 2016); Carlsson, Medborgarskap och diskriminering: Östjudar och andra invandrare i Sverige 1860-1920; Hammarström, "Judar öfversvämmar landet."

35 On the current state of Swedish scholarship in this regard, see Karin K. Geverts, "Antisemitism in Sweden: A Neglected Field of Research?" in Antisemitism in the North, ed. Jonathan Adams and Cordelia Heß (Berlin: De Gruyter, 2019); Jonathan Adams, “'Untilled Field' or 'Barren Terrain'? Researching the Portrayal of Jews in Medieval Denmark and Sweden,” in Antisemitism in the North; Cordelia Heß, "Nordic Otherness: Research on Antisemitism in the Nordic Countries in an International Context," in Antisemitism in the North.

36 Kurt Stillschweig, Judarnas emancipation. En återblick (Stockholm: Geber, 1943); Bernhard Tarschys, Judarna i Sverige 1775-1975 (Stockholm: Kungl. biblioteket, 1975); Marcus Ehrenpreis "När Mendelssohn och Lessing möttes. Kampen för judarnas emancipation," Judisk tidskrift Stockholm 16 (1943). 
and Russia changed the situation in the eyes of the Swedish population, which had come to terms with the relatively assimilated Jews from the German lands but not with the culturally and economically distinct östjudar. ${ }^{37}$ Predating the 1870 decision, many of these relations were hostile and, as elsewhere, debates surrounding Emancipation were only a small aspect of the broader development of anti-Jewish attitudes and behaviour. In Sweden and elsewhere, parliamentary debates and the ensuing legislation can only be seen as a partial and imperfect mirror or representation of relations between majority and minority - and in Sweden, most debates at the Riksdag before 1870 ended with a confirmation of the status quo, if not a deterioration in the status of the Jewish minority. ${ }^{38} \mathrm{Be}$ yond the parliamentary level, anti-Jewish attitudes manifested themselves and flourished on many different levels and in many different discursive arenas: religious didactics, disseminated as sermons and written communications within Christian communities and parishes; the arts and sciences and their textual production; newspapers; and general public communications in printed form. The entire nineteenth century was a period in which "the Jewish question" was debated in various contexts, forums, and discourses. Three areas of text production are particularly relevant: the annual debates in the Riksdag, in which various changes to the judereglemente were discussed almost biennially during this period; the daily and weekly newspapers, growing in importance both locally and nation-wide; and the production of books and pamphlets. The latter two in particular had benefited from the tryckfrihetsförordning (Freedom of the Press Ordinance) of 1812, which established freedom of the written word except in cases of national security and interest. Even though the category of sermons, the most important pre-modern and early modern medium of public education and information, is not included, religious texts and arguments also appeared in the realm of print; nonetheless, the oral and visual transmission of stereotypes in parish churches remains a topic for future studies. ${ }^{39}$

For continental Europe, particularly Prussia and France, the nineteenth century is generally considered the most important phase in the development of modern racist antisemitism as well as political antisemitism. The factors leading to these changes and modernizations of hostility towards Jews are evident in the Emancipation, in the social mobility Jews gained following the Emancipation,

37 See Bredefeldt, De judiska minoriteterna, 58-59.

38 See appendix 1 for a list of motions and debates regarding Jewish themes at the national diets from $1800-1900$.

39 One of the few previous forays into this field is David Tjeder, "Guds utvalda folk eller kroknästa messiasförnekare. Stockholmsprästeriets bild av judar 1750 -1830," in Svensk Antisemitism 1880 - 1930, ed. Mattias Tydén (Uppsala: Centre for Multiethnic Research, 1986). 
and in general fears of processes of liberalization and modernization which were projected onto the Jewish minority. Some scholars have also pointed to the changing role of religion and religious difference in societies which went through processes of secularization. ${ }^{40}$ At the same time, the presence of religiously grounded stereotypes in the anti-Jewish debates of the early nineteenth century has been seen as obvious. ${ }^{41}$

Jacob Katz has coined the term "Frühantisemitismus" for the period between the 1780 s and 1870, when medieval stereotypes merged into a modern, rationalized form:

Der Rationalismus der Aufklärung, der die tradierten christlichen Hemmnisse gegen die Gleichstellung der Juden abtrug, lieferte ebenso die anthropologische Sehweise, mit deren Hilfe man die gern akzeptierte Minderwertigkeit der Juden neu begründen konnte. Darin ist durchaus die erste Phase einer zur Rassentheorie tendierenden Entwicklung zu sehen. [...] Blieb aber das Christentum, sei es auch in ideologischer Abwandlung, eine konstitutive Macht im Bewusstsein der Zeit, so wurde die traditionelle Abwertung seines historischen Gegners, des Judentums, mit fortgepflanzt. Sowohl der ,rationalistische als auch der christliche Antisemitismus späterer Zeit sind in der Phase des Frühantisemitismus nicht nur ideell vorweggenommen, sondern im Kern real vorhanden. ${ }^{42}$

The term "Frühantisemitismus" has been criticized because it dates the emergence of antisemitism prior to the emergence of the terminology to describe it. On the other hand, it has been adopted and put to the test in literary, philosophical, and linguistic studies. Most scholars of the history of antisemitism agree that the late eighteenth and early nineteenth century was a period in which broader intellectual and political developments, principally the Enlightenment, influenced political emancipation as well as the ongoing prevalence of anti-Jewish stereotypes. The founding of the German Empire in 1871 and the defeat of France are seen as a major turning point for the emergence of antisemitism as a purely political and ideological movement, targeting not only civil Emancipation but also the social advancement of Jews in the bourgeois society of the Em-

40 For example, see Weyand, Historische Wissenssoziologie.

41 Christhard Hoffmann, "Christlicher Antijudaismus und moderner Antisemitismus. Zusammenhänge und Differenzen als Problem der historischen Antisemitismusforschung," in Christlicher Antijudaismus und Antisemitismus: Theologische und kirchliche Programme deutscher Christen, ed. Leonore Siegele-Wenschkewitz, Arnoldshainer Texte 85 (Frankfurt am Main: Haag + Herchen, 1994).

42 Jacob Katz, "Frühantisemitismus in Deutschland," in Begegnung von Deutschen und Juden in der Geistesgeschichte des 18. Jahrhunderts, ed. Ya'aḳov Kats, Wolfenbütteler Studien zur Aufklärung 10 (Tübingen: Niemeyer, 1994), 89. 
pire. When religion ceased to function as a social and political marker, race took its place, according to the established scholarly narrative. ${ }^{43}$

While this religious foundation was universal to Christian Europe, the theories and development of Frühantisemitismus in the specific political and social context of the German lands during the nineteenth century occurred in countries which had been home to old, stable, and large Jewish communities and which were split into Catholic and Protestant areas. The Christian religious roots of modern antisemitism have been the subject of debate; they are viewed differently by scholars of medieval and modern history, as well as from the perspective of theology or church history and that of social history. Scholars of Christian theology have tended to see a strong line of continuity between medieval and early modern Christian anti-Judaism and modern forms of hostility. The model established by social historians, however, with its emphasis on the socio-political circumstances leading to the Emancipation, became the dominant model for explaining the emergence of modern antisemitism. ${ }^{44}$

In the nineteenth century, religious aspects were also a focus of anti-Jewish arguments, as Judaism was seen as a remnant of medieval, pre-enlightened times. The Enlightenment was an intellectual movement, which landlords and rulers in certain minor territorial states took advantage of in order to modernize their economy and government. The Jewish communities varied in their economic and legal situation and numbers. Religious wars had been over for a century or two and the Reformations had produced a myriad of different denominations which had oppressed one another ever since. Moderate forms of religious toleration were deemed necessary in order to ensure the mobility of sought-after professional groups. None of these factors applies to Sweden (or Denmark, Norway, or Finland). In Sweden, Jewish immigration was only legalized in 1782, and the first royal decree allowing Jews to settle created a very particular situation and consequently a very particular Jewish community in the country. ${ }^{45}$ This minor liberalization of the otherwise extremely strict regulations tying civil rights to Protestantism was one of the very few examples which can actually be cited as evidence of enlightened thought in Sweden - in fact, scholars of the history

43 For a short summary of the very comprehensive literature using this line of explanation and definitions, as well as for the relevant contemporary literature, see Thomas Gräfe, "Antisemitismus im deutschen Kaiserreich. Stereotypenmuster, Aktionsformen und die aktuelle Relevanz eines "klassischen” Forschungsgegenstandes," Sozial.Geschichte Online 25 (2019).

44 Christhard Hoffmann, "Christlicher Antijudaismus und moderner Antisemitismus."

45 J. Zitomersky, "The Jewish Population in Sweden 1780-1980. An Ethno-Demographic Study," in Judiskt liv i Norden, ed. Gunnar Broberg, Harald Runblom, and Mattias Tydén (Uppsala: Acta Universitatis Upsaliensis, 1988). 
of ideas of the eighteenth century have made the claim that Sweden did not have an Enlightenment at all, that there was no area of science or society in which rationalism was brought together with a critique of religion and royal absolutism. ${ }^{46}$ Other scholars have seen a development from the Protestant religion being the main factor of national identity to a secularized form of nationalism; for example, in the small and gradual legislative measures to allow religious rituals in Sweden outside the churches ${ }^{47}$ - but this did not take legal form before 1858, with the abrogation of the law prohibiting such services (konventikelplakatet), which had served mainly to oppress Pietist and evangelical movements. Yet others have pointed to the significance of the Enlightenment and general ideas of tolerance for the Emancipation process. Per Hammarström, for example, sees a “de-dramatization of conversions" taking place around 1800, thereby allowing Jews to convert and be included in Swedish society ${ }^{48}$ - however, conversion as a prerequisite to integration can hardly be seen as an example of religious tolerance.

Even the degree of freedom brought about by allowing Jewish immigration must be qualified. The requirement of a relatively high personal income prior to immigration and the restriction and simultaneous privileging of trade, manufacturing, and a few available guild-free trades established the Jewish community as relatively rich, socially and economically homogenous, and easy to recognize as newcomers - all factors which made it easy to connect this group to older ideas about Jews as usurers, as primarily dealing with monetary affairs, and as a close-knit community ruled by ancient laws instead of the laws of the nationstates in which they lived. The judereglemente established the Jewish minority as an actual "colony" within Sweden, ${ }^{49}$ with different laws and privileges, and thereby as an actual caricature of the "state within the state."

The first Jewish immigrants to Sweden spoke German, many were related to each other and ran businesses together, and their settlement was restricted to three (later four and then five) towns. With these prerequisites, existing anti-Jewish stereotypes encountered a reality very different from that on the continent. While in Prussia, and even more so in Poland, for example, the rich Jewish moneylender was a stereotype corresponding to only a very small minority of Jews -

46 Tore Frängsmyr, Sökandet efter upplysningen: Perspektiv på svenskt 1700-tal, rev. ed. (Stockholm: Natur och kultur, 2005).

47 Carlsson, Medborgarskap och diskriminering: Östjudar och andra invandrare i Sverige 18601920, 26.

48 Hammarström, I sällskap med judar, 168.

49 This definition of the Jewish community's status was established by Hugo Valentin, see above. 
most of whom lived as relatively poor peddlers, small merchants, and craftsmen - in Sweden there were literally no Jewish moneylenders, but the entire community was relatively rich. Additionally, they had very good personal and professional connections to the German lands, particularly Hamburg and Mecklenburg, from where the first generations had immigrated. As early as the beginning of the century, the continent also knew different kinds of Jews: assimilated liberal groups, conservative ones, and the often poor and visually and culturally distinct Orthodox Jews from the East, who were frequently the target of stereotyping and who had little to do with the urban upper class who immigrated to Sweden.

There were 845 Jews in Sweden in 1825, 956 in $1850 . .^{50}$ There were no simultaneous liberalizations for Catholics or for non-Lutheran Protestant denominations before 1858, which made the Jewish minority stand out even more. Swedish society at the turn of the century was religiously largely homogenous, apart from some immigrant communities and the Sámi who had yet to be subjected to aggressive Christianization attempts. Non-Protestant religions were heavily restricted, Pietist movements persecuted, their immigration deemed illegal, and mixed marriages forbidden. There was no confessional culture in which the other Christian denominations provided a religious Other within the same language and later national community, and this informed a different view of religion as the basis of the nation-state - a view in which religious homogeneity was not just an ideal but largely a reality. Edicts of religious toleration, such as those that had already emerged in various German lands during the seventeenth century in order to regulate different Protestant denominations, ${ }^{51}$ were unknown. During the last three decades of the nineteenth century, the time at which such statistics

50 Carl Adolph Agardh, "Monopolium mot Judarne," in Försök till en statsekonomisk statistik öfver Sverige D. 2. H. 2 Om arbetet, afsättningen och svenska jordnaturen (Carlstad: Kjellin, 1856), 168-69. The numbers are from an antisemitic treatise, but match other available numbers on the matter. Regarding the Monopolium mot judarne, see below.

51 The best-known example of a German edict of toleration is the "Edikt von Potsdam" of 1685, which dealt with the admission of Huguenots: Barbara Dölemeyer, "Rechtliche Rahmenbedingungen der Hugenottenaufnahme in deutschen Territorien," Bulletin / Association Suisse pour l'Histoire du Refuge Huguenot 25 (2004). Even before that, however, there had been edicts addressing the conflicts between Lutherans and Calvinists in Prussia, the so-called "zweites Toleranzedikt” of 1664 being the most significant: Johannes M. Ruschke, Paul Gerhardt und der Berliner Kirchenstreit: Eine Untersuchung der konfessionellen Auseinandersetzungen über die kurfürstlich verordnete 'mutua tolerantia', Beiträge zur historischen Theologie vol. 166 (Tübingen: Mohr Siebeck, 2012). 
first become available, immigration did not surpass a few thousand people per year, and most of these came from one of the other Nordic countries. ${ }^{52}$

This context of religious homogeneity fostered anti-Jewish as well as antiCatholic hostility and Othering; for both groups, a lack of loyalty to the nation-state was assumed and different European variants of the "state-withinthe-state" theme merged. For the Jewish minority, religious hostility based on the accusation of deicide was amalgamated into a general idea of Jews as murderous, mean, and evil - even though the Catholic motifs of host desecration and ritual murder proved difficult to adapt to Protestant Sweden. Additionally, the question of chosenness, one of the central controversies between Jewish and Christian theologies, was highly significant. It was grounded in the Church Fathers' supersessionist beliefs, the idea that the covenant between God and Christians as established by the sacrifice of Jesus Christ superseded the old covenant between God and the Jewish people. But probably even more relevant than the theological debates rooted in supersessionism was the secularization of the idea that the Jews consider themselves to be the chosen people. In this context, chosenness does not reflect the idea that Jews have been selected by God to bear the yoke of the commandments and to act as a light unto the nations but rather that they consider themselves to be something special, above non-Jews, and select.

In terms of economic structure, Sweden was at that time a rural, relatively poor, and rigidly hierarchical society. While most peasants were free and many owned land, the population growth in the second half of the century, the result of vaccinations and potatoes, led to a growing number of dispossessed farmers who worked as day labourers or on small farmsteads belonging to larger estate owners. The rate of urbanization was very low but rapidly growing: Stockholm had about 75,000 inhabitants in 1800 and 300,600 in 1900, Gothenburg and its surroundings had around 20,000 in 1800 and 145,000 in 1900. In 1800, the entire country had about 2.3 million inhabitants, in 1900 it had 5.1 million and this was after the massive emigration to the United States in the second half of the century, during which 1.4 million Swedes left the country. ${ }^{53}$ These numbers indicate that fundamental demographic and social changes were taking place, especially in the urban centres of Stockholm, Gothenburg, and Karlskrona (which had only slightly less inhabitants than Gothenburg), and these three cities were also the places where Jewish settlement was allowed. It is

52 Statistiska centralbyrån, Sveriges folkmängd från 1749 och fram till idag, https:// www.scb.se/hitta-statistik/artiklar/2017/sveriges-folkmangd-fran-1749-och-fram-till-idag/.

53 Statistiska centralbyrån, Historisk statistik för Sverige: Del 1. Befolkning 1720-1967, 2nd ed. (Stockholm: AB Allmänna Förlaget, 1969), Tab. 7. Folkmängden i städerna länsvis 1800-1960. 
thus tempting to see the development of antisemitism in connection with modernization, urbanization, population growth, and social mobility - as was the case for Jews in Prussia, where previous research tended to see the development of political antisemitism after 1870 as being a result of the Jews' position as winners of modernity. ${ }^{54}$

But this purely socio-historical explanation of antisemitism in Sweden would neglect a number of factors. The history of the nineteenth century in Sweden was fundamentally different from in Prussia, where the Emancipation of Jews was declared in 1812 following decades of debate. The development of political antisemitism, however, did not gain traction until it merged with the questions of national unity that would culminate in the foundation of the German Empire in 1871. Sweden did not have a national question, but it did experience a massive shift in the social and political system. The nineteenth century started with a change in the succession with the foundation of the French Bernadotte dynasty - its first king, Karl XIV Johan, being a convert from Catholicism and would bear witness to the final end of the stormaktstid (period as a great power) with the loss of Finland and Norway's gaining relative independence within the union. Prior to 1878, Sweden had one colony left overseas (St. Barthélemy); at the same time, it was intensifying its colonial grasp on the Sámi areas and culture. Inside Swedish society, a fundamental shift was taking place - the early nineteenth century formed what Torkel Jansson has referred to as the "sprängfyllda tomrummet mellan två samhällsformationer" (the jam-packed vacuum between two societal formations), the old one based on privileges and estates and the new one based on individual enterprises and the formation of a capitalist market. ${ }^{55}$ All of these factors should make one wary about applying continental explanations of the development of antisemitism to Sweden - even though there are clear similarities in the text production, as will be shown.

For about 20 years in the early nineteenth century, the Swedish Riksdag debated various attempts to change the regulations of the 1782 judereglemente most of them to the disadvantage of the minority. During these two decades, anti-Jewish print production focusing on the question of emancipation in Sweden became more professional, more international, and also more hostile. A major turning point occurred in 1838, when King Karl XIV Johan attempted to re-

54 Ulrich Wyrwa, "Zur Entstehung des Antisemitismus im Europa des 19. Jahrhunderts: Ursachen und Erscheinungsformen einer wahnhaften Weltanschauung," in Antisemitismus im 19. Jahrhundert aus internationaler Perspektive: Nineteenth Century Anti-Semitism in International Perspective, Schriften aus der Max Weber Stiftung Band 1, ed. Mareike König and Oliver Schulz (Göttingen: V\&R Unipress, 2019).

55 Hammarström, I sällskap med judar, 157-58. 
scind the judereglemente. Although he was supported by the local administration in those areas where Jews had settled, as well as by the Board of Commercial Affairs, he was forced to reinstitute it following major protests, most of which occurred in the capital.

The series of events were as follows: On 30 June of that year, the king published a renewed regulation for the Jewish community, which effectively rescinded the restrictions of the judereglemente regarding immigration and granted full civil rights to those Jews already in the country. The edict was published in the newspapers and was also printed separately. ${ }^{56}$ Over the following weeks, the Stockholm newspapers initiated a comprehensive campaign in which the "Jewish question" was presented first as a topic, then as a problem. For two weeks, a mob of as many as several hundred people rioted in the city, throwing stones at Jewish private houses as well as at the house belonging to Carl Skogman, the head of the chamber of commerce, who had signed the edict. No one was hurt, but together with the newspaper campaign, the king deemed the riots serious enough to warrant revoking the emancipation edict two months later.

All of these factors suggest that the development of antisemitism in Sweden must have differed from that on the continent. The argument that religious antisemitism disappeared and was replaced by political and racist antisemitism, as has been claimed by German scholars in particular, and the widely accepted periodization of how antisemitism developed in connection with the German statebuilding process must be challenged in regards to Nordic relations. The characteristics of Frühantisemitismus - a form of antisemitism in which religious stereotypes merged with racism - were already visible in the Swedish print production of the first decades of the nineteenth century. Religious anti-Jewish texts appeared throughout the century. However, none or very few of the historical, political, and social factors which have been advanced as preconditions for the development of this early antisemitism on the continent, particularly in the German-speaking areas, were present in Sweden.

56 Kongl. Maj:ts nådiga kungörelse rörande tillämpningen i vissa fall af dess under den 30 sistlidne junii utfärdade nådiga förordning, angående mosaiske trosbekännares rättigheter och skyldigheter här i Riket; gifwen Stockholms slott den 21 september 1838 (Stockholm: Norstedt \& Söner, 1838). 


\section{The Swedish debate in an international context}

The Nordic societies had been producing and disseminating anti-Jewish texts ever since the arrival of Christianity and Latin literacy, and religiously based stereotypes centring on themes such as deicide, general evil, bloodlust, or deformed bodies were well known. ${ }^{57}$ However, during the Reformation, Martin Luther's most explicitly anti-Jewish books were not translated, and the Swedish reformers were less interested in the topic - probably because the Lutheran dichotomy of law versus spirit served as a more powerful incentive for religious identity when both Catholics and Jews were present to illustrate the opposite poles. ${ }^{58}$ During the Reformation in Sweden, Catholics made much more sense as an enemy than Jews, and Luther's admonitions to the secular rulers to expel all Jews from Christian lands were not applicable in a country with no established Jewish presence. Nonetheless, the Swedish reformers had strong connections to Luther and to Wittenberg, studied and learned in the centre of the Lutheran Reformation, and were obviously familiar with this part of the Protestant tradition. Yet our knowledge about the transmission and development of anti-Jewish thought in Sweden during the early modern period is rudimentary. Even for the nineteenth century, most studies have focused on the last third of the century, after Jews had been granted civil rights, and have examined demographic and economic factors rather than ideology ${ }^{59}$ We lack systematic research on the development of anti-Jewish thought in Sweden before the Emancipation or even be-

57 In particular, see Jonathan Adams's publications on the representation of Jews in East Norse texts.

58 For a Danish view on Luther's anti-Jewish writings, see Martin Schwarz Lausten, Luther og “de fremmede”: Martin Luthers syn på jøden og tyrken (Frederiksberg: Eksistensen, 2017).

59 Henrik Edgren, "Societal Change, Economic Decline and National Identity: The Debate About Jews in Sweden in the Early Nineteenth Century," in The Exclusion of Jews in the Norwegian Constitution of 1814: Origins - Contexts - Consequences, Studien zum Antisemitismus in Europa 10, ed. Christhard Hoffmann (Berlin: Metropol, 2016); Carl Henrik Carlsson, "Immigrants or Transmigrants? Eastern European Jews in Sweden 1860-1914," in Points of Passage: Jewish Transmigrants from Eastern Europe in Scandinavia, Germany, and Britain 1880-1914, ed. Tobias Brinkmann (New York: Berghahn Books, 2013); Carlsson, Medborgarskap och diskriminering; Per Hammarström, "I sällskap med judar. Association, assimilation och konversion i Stockholm 1809-1838," in Nationen så in i Norden: Festskrift till Torkel Jansson, Studia historica in honorem Torkilli Helsingii edita 1, ed. Henrik Edgren (Skellefteå: Artos \& Norma Bokförl, 2013); Artur Attman, "Judiska insatser i Göteborgs samhällsutveckling," in Göteborgs mosaiska församling 1780 - 1980. Minnesskrift till Göteborgs mosaiska församlings 200-års jubileum (Göteborg: Församlingens förlag, 1980). 
fore the 1930s, despite several studies on particular events or shorter time periods. ${ }^{60}$

Even for the other Nordic countries, research on the historical development of antisemitism in connection with nineteenth-century Emancipation debates has been scarce. The exclusion of Jews from the Eidsvoll constitution, the first constitution of Norway in 1814, has only recently been the subject of an international conference and resulting anthology ${ }^{61}$ as well as a monograph by Håkon Harket. ${ }^{62}$ Recent work by Frode Ulvund highlights the Norwegian case and discusses anti-Judaism in connection with anti-Catholicism. ${ }^{63}$ For Denmark, the jødefejden of $1813^{64}$ and the case of Georg Brandes have been points of interest, ${ }^{65}$ as have anti-Jewish positions held by some prominent members of the Danish Church, ${ }^{66}$ while general studies of Jewish life in the country before the twentieth century remain rare. ${ }^{67}$ For Finland, the idea remains prevalent that the country basically has no issues with antisemitism and never did; however, Paavo Ahonen and Tarja-Liisa Luukkanen have shown that at least in the Finnish Church, antiJudaism was widespread at the end of the nineteenth century. ${ }^{68}$

60 Mattias Tydén, ed., Svensk antisemitism 1880-1930 (Uppsala: Centre for multiethnic research, 1986); Svante Hansson, “Antisemitism i Sverige på 1900-talet. En samlingsrecension,” Rambam. Tidsskrift för jødisk kultur og forksning 9 (2000).

61 Hoffmann, The Exclusion of Jews in the Norwegian Constitution of 1814.

62 Håkon Harket, Paragrafen: Eidsvoll, 1814 (Oslo: Dreyer, 2014).

63 Frode Ulvund, Fridomens grenser 1814-185: Håndhevinga av den norske "jødeparagrafen" (Oslo: Scandinavian Academic Press, 2014). On Jewish life in Norway prior to the twentieth century more generally: Oskar Mendelsohn, Jødenes historie i Norge gjennom 300 år (Oslo: Universitetsforlaget, 1969).

64 Therkel Stræde, “The 'Jewish Feud' in Denmark 1813," in The Exclusion of Jews in the Norwegian Constitution of 1814, ed. Hoffmann; Leif Ludwig Albertsen, Engelen mi. En bog om den danske jødefejde. Med en bibliografi af Bent W. Dahlstrøm (København: Privattryk, 1984).

65 Søren Blak Hjortshøj, “Georg Brandes’ representations of jewishness: between grand recreations of the past and transformative visions of the future" ( $\mathrm{PhD}$ Dissertation, Roskilde Universitet, 2017).

66 Martin Schwarz Lausten, Jøder og kristne i Danmark: fra middelalderen til nyere tid, Kirkehistoriske studier III, række, nr. 17 (København: Forlaget ANIS, 2012).

67 Merete Christensen and Brita Syskind, “De danske jøders livsvilkår 1814-1905," in Indenfor Murene: Jødisk liv i Danmark 1684-1984. Udgivet af Selskabet for Dansk Jødisk Historie i anledning af 300-året for grundlæggelsen af Mosaisk Troessamfund, ed. Harald Jørgensen (København: C.A. Reitzel, 1984); Inger Dübeck, "Fremmedrettens udvikling i Danmark ca. 17001914," in Fremmede i Danmark: 400 års fremmedpolitik, Odense University Studies in History and Social Sciences, vol. 104, ed. Bent Blüdnikow (Odense: Universitetsforlag, 1987).

68 Paavo Ahonen, Antisemitismi Suomen evankelis-luterilaisessa kirkossa 1917-1933, Suomen Kirkkohistoriallisen Seuran toimituksia, vol. 233 (Helsinki: Suomen Kirkkohistoriallinen Seura, 2017); Paavo Ahonen, Simo Muir, and Oula Silvennoinen "The Study of Antisemitism in Finland: 
Given that very little is currently known about the Emancipation process in Sweden, a number of questions arise from what we know about the process in other countries. These pertain to international influences on Swedish discourses and policies and to potential similarities and differences in this country. Particularly in Prussia, civil Emancipation led to a merging of religious and racist stereotypes, promoted in part by clergymen but mainly by those political movements that formed specifically in order to fight Jewish Emancipation. ${ }^{69}$ Did a distinct antisemitic movement develop within Swedish society? If so, what institutions and groups were involved, and did they use printed materials in order to disseminate their ideology? If not, why not? Was Emancipation in Sweden connected to calls for assimilation, as in the German lands? Or was it more like Denmark, where this was not the case?

Chronological coincidences can also be investigated: Denmark was the only Nordic country the Hep-Hep riots spread to. What was happening in Sweden at the time? In general, how were the "milestones" against Emancipation in Sweden (judefejden in 1815, failed Emancipation in 1838) connected to political developments on the continent and in the North?

The reign of King Karl XIV Johan (1818-1844) also marked a noteworthy difference in Sweden's political landscape: In the German lands, the liberal bourgeoisie has been identified as the strongest supporter of Jewish Emancipation. ${ }^{70}$ In Sweden, the first liberals opposed the conservative reign of the king, demanded more powers for the Riksdag, economic liberalizations, etc. - but since Karl XIV Johan was himself liberal on the question of Jewish Emancipation, Swedish liberals reflexively opposed him in this regard. For example, liberal positions appeared alongside anti-Jewish positions in the newspaper Aftonbladet.

The other Nordic countries are obvious reference points for the Swedish Emancipation process; however, this is not reflected in the Swedish print production, which draws much more inspiration from German, French, and English

\footnotetext{
Past, Present, and Future," in Antisemitism in the North, ed. Adams and Heß; Tarja-Liisa Luukkanen, "The Jewish Conspiracy Revealed (1897). Adolf Stöcker and the 19th-Century Antisemitism in Finland," QUEST Issues in Contemporary Jewish History, no. 07 (2014).

69 Reinhard Rürup, "Das preußische Emanzipationsgesetz von 1812 und die deutsch-jüdische Geschichte im Zeitalter der Emanzipation,” in Jüdische Lebenswelten: Von der Antike bis zur Gegenwart, ed. Ernst Baltrusch and Uwe Puschner (Frankfurt am Main: Peter Lang, 2016); Jan Weyand, "Die Entstehung der Antisemitismustheorie aus der Debatte über die Judenemanzipation," in Beschreibungsversuche der Judenfeindschaft: Zur Geschichte der Antisemitismusforschung vor 1944, Europäisch-jüdische Studien. Beiträge Band 20, ed. Hans-Joachim Hahn and Olaf Kistenmacher (Berlin, Germany: De Gruyter Oldenbourg, 2015).

70 See, for example: Shulamit Volkov, Antisemitismus als kultureller Code: Zehn Essays, Beck'sche Reihe 1349 (München: Beck, 2000).
} 
texts. Similar to Sweden, Norway's brand-new constitution in 1814 also barred Jews from entering the country. The Danish law of 1814 established the king's control over the Jewish community, ranging from the salary for rabbis to a catechism-like book of examination made compulsory for the young. Community members were to be enrolled in tax registers administered by Christian parishes. The Swedish king was attempting something similar with the 1838 law but failed. How important did royal control of internal Jewish organization and religion figure in the public debate about Emancipation?

Not all of these broader questions can be answered by examining the specific debates that took place in printed books and pamphlets. There are numerous references to Jewish-Christian relations in other countries, however, and it is particularly interesting how translators and publishers argued for the publication of foreign anti-Jewish texts in Sweden. In general, it must be observed that Danish and Norwegian texts and authors were not often translated in Sweden - probably because their books were accessible and could be read without translation - and neither Denmark nor Norway were important reference points in Swedish works debating Emancipation. In terms of both quantity and quality of translated texts, and in terms of examples cited, the German lands were the most significant international point of reference and, amongst these, Protestant Prussia was preeminent.

\section{Anti-Jewish print production in Sweden: The scope of the present study}

The Swedish kings established Freedom of the Press Acts early on: the first in 1766, a radical one in 1809, and then a revision in 1812 which remained in place until after the Second World War. Swedish book and leaflet printing involved different genres and formats, was situated throughout the country, and was relatively free of royal and government repression. The invention of the mechanical press in 1829 and the subsequent use of wood-based paper increased the consumption of newspapers, while the production of books increased slowly but steadily over the century. The Royal Library in Stockholm (Kungliga biblioteket, $\mathrm{KB}$ ) has been collecting at least one copy of every printed item in the country since the seventeenth century. This provides a unique corpus of sources in which a relevant part of public debates and discourses can be analysed. It is a blessing and a burden for a historical study because the collection is so comprehensive and does not distinguish between two-page leaflets and thick books. It also contains the troublesome corpus of government publications, i.e., communications from the government containing regulations, material from the Riksdag and 
members of parliament, laws and preparatory examinations for new legislation, legal court decisions and papers, and more. These often addressed topics related to Jews and, therefore, make up quite a substantial part of both the country's overall print production and the corpus of interest to this study - however, they are of limited value to a history of anti-Jewish knowledge except in so far as they testify to the significance of the "Jewish question" on all levels of administration and politics.

The print production, varied as it was in terms of authors, topics, and discourses, provides only a small portion of the discourse on Jews and Emancipation. The political arena is represented in the offentliga tryck, but these do not fully reflect the debates and hearings which surrounded and preceded decisions and the eventual Emancipation. In extensive surveys, Hugo Valentin has addressed the debates in the Riksdag and has reproduced a number of the key speeches made there, both for and against Jewish Emancipation. ${ }^{71}$ Several unpublished master's theses analyse these debates as well. ${ }^{72}$ I myself have analysed media debates around the failed Emancipation in 1838 and the related anti-Jewish street violence. ${ }^{73}$ In the following study, I will focus on print production during the years between 1800 and 1900 addressing any aspect of Jewish life, faith, or Emancipation. In most cases, the topic is already indicated in the title (judar, judisk, hebreisk, israelitisk, etc.). Additional texts have been found via the snowball method: books mentioned in other books, book advertisements, titles in the same series or by the same authors. The corpus is not defined by a specific discourse but by a medium - printed books and leaflets - which brings together various discourses and merges them together. Newspapers, however, are excluded, as are magazines. Texts containing anti-Jewish attitudes in connection with or overshadowed by other topics will in most cases not be covered by this search method. However, this approach should still be useful in order to provide a synopsis of those works that deal exclusively with the topic - while those

71 Hugo Valentin, Judarnas historia i Sverige (Stockholm: Bonnier, 1924).

72 Anna Karlsson, "Vägen till emancipation. Svensk riksdagsdebatt under 1850-talet om judarnas medborgerliga rättigheter” (BA dissertation, Örebro University, 2010); Simon Victorin, “Judefrågan på 1840 - 1841 års riksdag. Emancipation eller förtryck” (BA thesis, Stockholms univ., Historiska institutionen, 1997).

73 Cordelia Heß, "Eine Fußnote der Emanzipation? Antijüdische Ausschreitungen in Stockholm 1838 und ihre Bedeutung für eine Wissensgeschichte des Antisemitismus," Jahrbuch für Antisemitismusforschung 27 (2018). Regarding minorities, the discourse in newspapers has been studied for a slightly earlier period: Magnus Nyman, Press mot friheten: Opinionsbildning i de svenska tidningarna och åsiktsbrytningar om minoriteter 1772-1786, Acta Universitatis. Upsaliensis Studier i idé- och lärdomshistoria 3 (Uppsala: Universitetstryckeriet, 1988). 
that deal with something else and mention Jews in connection with other topics are missing.

$\mathrm{KB}$ has been collecting single copies of anything printed in Sweden since 1661, so the collection can be regarded as relatively complete regarding editions it cannot, however, be regarded as exhaustive when it comes to locating texts with (anti-)Jewish themes, due to very inconsistent standards in indexing, tagging, and digitization. The safest leads have been book titles in which some reference was made to Jewish themes, though some of these might have not been identifiable in the older card catalogue. Author names have not been very helpful, because many published only a single text on the topic, and the rest of their writings were on completely different matters. Series edited by a single institution, such as Föreningen för Israelsmissionen, appear only towards the end of the century. In some cases, advertisements on book covers led to additional finds, or the texts themselves referred to other texts, which were subsequently analysed.

This methodological restriction leads to an overemphasis on texts in two fields: first, religious treatises and legends, and second, texts that primarily debate Jewish Emancipation. The previously mentioned offentliga tryck make up a small subcategory of the latter; this included royal announcements amending the judereglemente and also even key speeches and motions delivered in parliament regarding these amendments, whose authors deemed them worthy of separate publication in order to reach a broader public. Offentliga tryck thus certainly add to the presence of Jewish themes in the printed public sphere, but their abundance poses a challenge to quantitative observations.

Besides religious and Emancipation-centred political texts, there are also a significant number of texts that mention Jews in a seemingly humorous, satirical, or poetic way - indicating that this minority was a topic of interest out of proportion to their actual numerical presence in Sweden at the time. The medium of printed books and leaflets makes a geographical connection to audiences impossible - it may be assumed that the texts were read (and in some cases, definitely were printed) in towns and areas with no Jewish community, and that the topic was considered relevant independent of the actual presence of Jews. ${ }^{74}$

The survey of the catalogue of Swedish printed matter produced roughly 100 individual texts, of which roughly two thirds were Swedish originals. Of the translations, those from German constituted an absolute majority, though there were also a handful from French and English. A small number were pub-

74 For more on the non-connection between Jewish presence and antisemitism, see Heß, "Nordic Otherness." 
lished in two or more editions. The absolute champion in this regard was the legend of Ahasver/Ahasverus or the Wandering Jew; originally translated from Dutch, it was printed in several versions starting in 1643, as many as 24 editions being published between the years 1823 and 1891. The best most other texts reached was two or three editions within a span of ten years or so.

It might be assumed that more texts would be printed in periods marked by specific events regarding the Jewish minority. But this does not seem to be the case - years of fierce political debates in parliament, or with significant changes to the law regarding Jewish settlement, did not witness increased book production. Instead, a nearly even distribution of texts over the decades can be observed, with the exception of the year 1815, as mentioned above. The actual Emancipation in 1870 did not provoke a significant increase in print production on the topic - at least nothing that cannot be explained by the general increase in the number of printed books towards the end of the century.

It should be noted that the corpus also contains a number of publications issued by the Jewish community itself, starting at the time of their naturalization in 1782. During the first decades, these publications were mainly Swedish translations of Hebrew prayers and songs of praise which were used in the community to mark various occasions - wars, the king's birthday, return from a battle, the opening of a synagogue, or general feast days. Since the first generations of Jewish immigrants spoke German rather than Swedish, these texts were probably intended to provide the Christian Swedes with some insight into the "secrets of the Jews," and as such likely constituted a precautionary measure. In later years, a number of legal documents from and for the Jewish community were printed as well. Some books contained translations of famous German rabbis, such as Abraham Geiger ${ }^{75}$ and Ludwig Phillippson. Also, Moritz Wolff, a rabbi in Gothenburg from 1851 to 1899, published several books on Jewish topics. ${ }^{76}$ Nathan Birnbaum's Zionist ideas were translated into Swedish and printed in Helsinki. ${ }^{77}$ Towards the end of the century, Gottlieb Klein was appointed rabbi in Stockholm after having emigrated from Austria. He published widely, explaining his liberal perspective on Judaism, and lectured at Uppsala University, receiving the title of professor there. His public lectures were sometimes published, one example being Står Gamla Testamentets moralverkligen på barbarernas utvecklings-

75 Abraham Geiger, Nödvändigheten af reform inom den judiska gudstjänsten och grunddragen för en sådan; jämte en skrivelse af G. Klein (Stockholm: Isaac Marcus boktr.-aktiebolag, 1893). 76 Moritz Wolff, Bidrag till filosofiens historia med särskildt hänseende till den judiska religionsfilosofien (Stockholm: Albert Bonnier, 1882).

77 Nathan Birnbaum, Det judiska folkets pånyttfödelse i dess eget land som medel till lösningen af judefrågan: en appell till de goda och ädla af alla nationer; öfvers af E. J. (Helsingfors, 1894). 
skede ${ }^{78}$ As these texts do not pertain to the reconstruction of an antisemitic archive of knowledge they will be mentioned as part of the corpus on "Jewish themes" but will not be analysed specifically. It should also be mentioned that some of the anti-Jewish texts provoked rebuttals, often from anonymous authors, some of whom hinted at their belonging to the Jewish community. There were extremely few non-Jewish authors, however, who came forward publicly as defenders of Jewish Emancipation; only really the previously mentioned Carl August Grevesmöhlen and Erik Magnus Pontin.

Biblical and ancient history constitute another category of publications which will not be analysed in this study. Translated scholarly works, historical sources, and studies from the Chair of Old Testament Studies in Uppsala were produced and disseminated, regarding subjects ranging from Flavius Josephus to the history of the Jewish people in the Persian Empire to the Maccabean wars. In recent years, the way in which European Orientalism has informed the history of academic departments and fields of study has attracted some attention; in this regard, the effect of antisemitism on the intellectual and institutional development of departments of Oriental languages in Sweden is certainly relevant, but it is beyond the scope of this study.

Specifically in regards to the translations, the names of famous foreign authors were often used as a means of legitimizing the text, and forewords pointed out that famous or well-known or well-read author so-and-so had written the book in question and that his knowledge would be of benefit in the Swedish situation as well. Most of the books and booklets were published anonymously, though.

\section{Statistics}

As the accessibility of the corpus is determined by the cataloguing system of KB, the results cannot be considered exhaustive or complete. Furthermore, the quantitative analysis changes from day to day, as more and more publications appear in the electronic cataloguing system and thus become available with the search methods used here. About 132,000 individual printed texts from between 1800 and 1899, in Swedish and from Sweden, are indexed in KB's national catalogue Libris. It is difficult to extrapolate the number of books and pamphlets from the number of indexed items, due to the extensive character of the Swedish law re-

78 Gottlieb Klein, Står Gamla Testamentets moral verkligen på barbarernas utvecklingsskede? Föredrag öfver Letourneaus bok “Moralens utveckling” (Stockholm: Bonnier, 1892). 


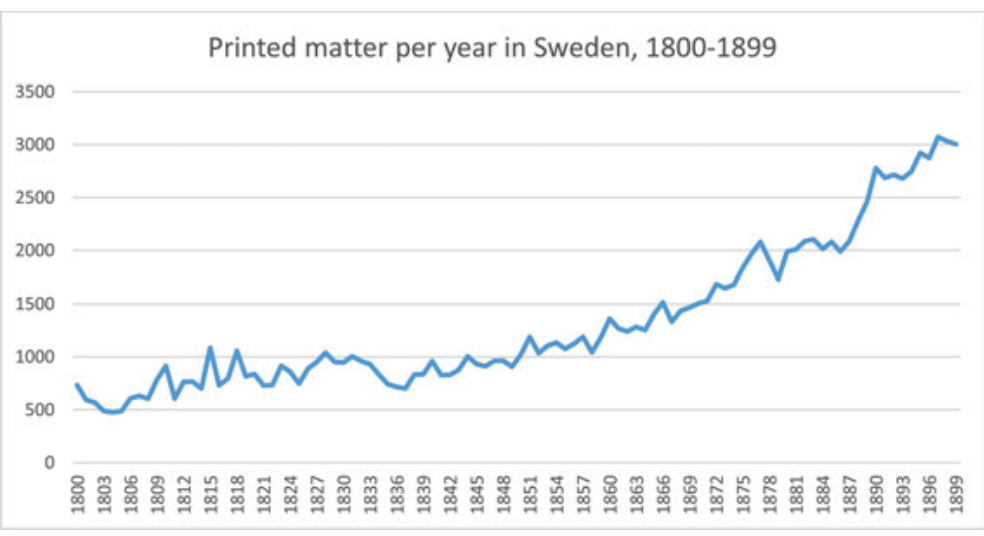

Fig. 1: Swedish printed matter produced per year, 1800-1900. Source: Libris, Swetryck. Graph by Erik Wolf.

quiring that one copy of each printed product be stored. Consequently, of the 132,000 prints, various categories of print products must be subtracted in order to get an accurate sense of the number of books printed during the nineteenth century. A general observation is that before the middle of the century, the number of publications rarely exceeded 1,000 exemplars per year, with peaks in $1815,1818,1831$, and 1844. From about 1850 on, the number increased slowly but steadily, and in the last decade, between 2,700 and 3,000 Swedish-language publications were being produced in Sweden every year.

Not all of this printed matter consists of books, and this points to the complications posed by the cataloguing system and the priority KB gives to digitizing certain materials before others. The printed matter in question includes daily and weekly newspapers, posters and pictures, journals, sheet music, serials, yearbooks and calendars, and maps. A considerable proportion of the existing catalogue entries also comprise price lists of various Swedish factories and their products, and catalogues of either products or libraries. Four thousand three hundred indexed items are in reality collections of various printed products, from individuals or companies. A number of items are indexed several times with only slightly differing titles; these are in some cases mistakes, in others duplicate editions from the same year. Each edition of each text is indexed separately. A smaller quantity of printed matter is not indexed, even though it fulfils all the relevant criteria; these items are indexed in the library's old Plåten card catalogue system - since these entries are transferred to the digital catalogue as the titles are requested by users, the gaps in the digital catalogue are constantly getting smaller. 


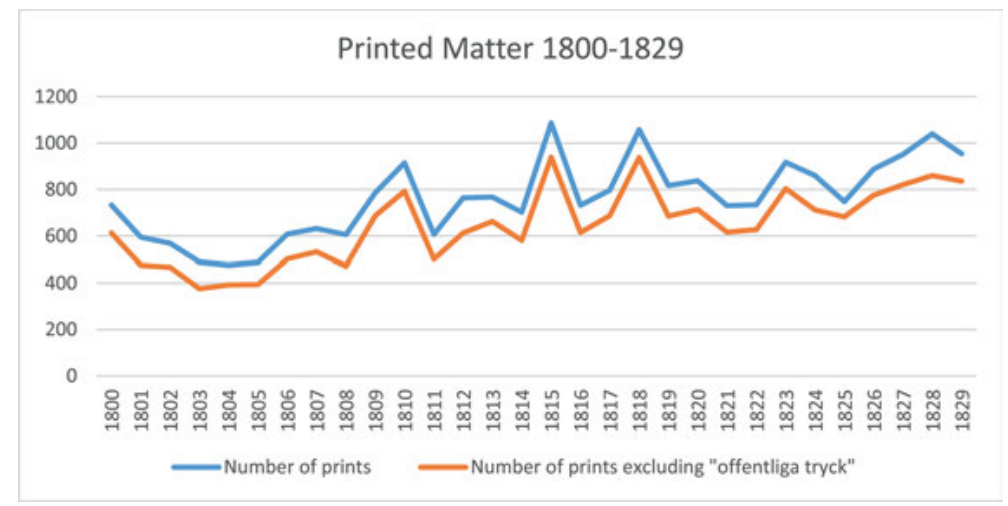

Fig. 2: Printed matter produced per year, including and excluding offentliga tryck, 1800 1829. The numbers are deducible through a comparison between the Libris and Swetryck catalogues (the latter only covers the years up to 1829). Graph by Erik Wolf.

For a quantitative analysis of the representation of Jewish themes in Swedish print production, offentliga tryck poses a serious problem of source criticism, as mentioned above. The printed announcements from the government are contained in the print collection of $\mathrm{KB}$ and in the catalogues, and the number of them that are catalogued properly and digitized is disproportionately large compared with other types of texts. It is, however, not possible to subtract their number from the overall number of printed books, nor can one exclude them from the overall number of books printed on Jewish topics. Jonas Nordin has tried to calculate the percentage of offentliga tryck in relation to the total print production for the period 1719-1814 and has also explained the unavoidable uncertainties deriving from quantitative analysis based on the Swedish library catalogues. ${ }^{79}$ Similar problems occur for the rest of the nineteenth century, and the amount of offentliga tryck addressing Jewish themes is therefore striking but needs to be weighed against their over-representation in the cataloguing system.

79 Jonas Nordin, "En revolution i tryck. Tryckfrihet och tryckproduktion i Sverige 1766-1772 och däromkring," Vetenskapssocietetens årsbok (2020). I would like to thank Jonas Nordin for his help with the intricacies of the cataloguing system. 